\title{
Identification of the profile of endogenous cytokinin-like compounds during different plant growth stages and their effects on flower bud abscission in pistachio (Pistacia vera L.)
}

\author{
Muhammet Ali Gundesli, ${ }^{1, *}$,Salih Kafkas ${ }^{2}$, Murat Guney ${ }^{3}$, Nesibe Ebru Kafkas ${ }^{2}$ \\ ${ }^{1}$ East Mediterranean Transitional Zone Agricultural Research Institute, Kahramanmaras, Turkey \\ ${ }^{2}$ Department of Horticulture, Faculty of Agriculture, University of Cukurova, Adana, Turkey \\ ${ }^{3}$ Department of Horticulture, Faculty of Agriculture, University of Yozgat Bozok, Yozgat, Turkey
}

\begin{abstract}
Alternate bearing is a significant economic problem that affects fruit producers, consumers and the economy of a country. Concentrations of cytokinin (CK)-like compounds in different tissues of pistachio trees (Pistacia vera 'Uzun') were measured to elucidate the relationship between endogenous CKs and flower bud abscission (alternate bearing). Identification and quantification of CK-like compounds of the Z, DHZ and iP types from different physiological stages and tissues were performed using high-performance liquid chromatography-electrospray ionisation-tandem mass spectrometry (HPLCESI-MS/MS) techniques. Five to seven different CK-like compounds were detected, respectively. Isopentenyl adenine riboside (iPR) and trans-zeatin- $O$-glucoside ( $t$-ZOG) were the main isoprenoid CKs, as the dominant conjugates in all the analysed organs of pistachio trees. The leaves and shoots of 'On'-year trees had significantly higher CK contents than those of 'Off'-year trees on all the sampling dates. Interestingly, the relatively high CK activity was recorded before flower bud abscission in the fractions corresponding to iPR and $t$-ZOG, while this activity dropped considerably during the flower bud abscission period (55 DAFB). Consequently, the strong negative correlation between CK concentration and bud abscission could be the first indication of the role of CK-like compounds in this unique phenomenon in the 'Uzun' pistachio cultivar. It was concluded that CKs could have an important role in the alternate bearing in pistachio.
\end{abstract}

Keywords: alternate bearing, cytokinin-like compounds, Pistacia vera L.

\begin{abstract}
Abbreviations:
c-Z, cis-Zeatin; c-ZR, cis-zeatin riboside; c-ZOG, cis-zeatin-O-glucoside; DHZ, dihydrozeatin; DHZR, dihydrozeatin riboside; iP, $\mathrm{N}^{6}$-isopentenyl adenine; iPR, $\mathrm{N}^{6}$-isopentenyl adenosine riboside; $t$-Z, trans-zeatin; $t$-ZR, trans-zeatin riboside; $t$-ZOG, trans-zeatin- $O$-glucoside; HPLC-ESI-MS/MS, high-performance liquid chromatography-electrospray ionisation-tandem mass spectrometry.
\end{abstract}

\section{INTRODUCTION}

Pistachio (Pistacia vera L.), a member of the Anacardiaceae family, is an important nut crop of Turkey and has a long history in that country. In particular, the Southeastern Anatolia region is well suited for pistachio cultivation due to its suitable climate conditions and thus it holds $95 \%$ of the total pistachio growing area which covers $91.5 \%$ of pistachio production in Turkey (Yavuz, 2011; Gundesli, 2017). P. vera 'Uzun' is the most popular cultivar, contributing more than $60 \%$ of the total production in Turkey. One of the main problems in pistachio production is the phenomenon of alternate bearing (irregular crop load) and flower bud abscission. 
Pistachio trees show some physiological disorders such as abscission of flower buds and fruit, production of empty fruit, unsplit nutshells and deformed nuts. Alternate bearing is identified by a year of bumper nut load, referred to as the 'On' year, followed by a year with an extremely light, light or no fruit load, called the 'Off' year in pistachio. This phenomenon is a problem not only in pistachio trees but also in several other fruit trees such as mango, olive and citrus (Vemmos, 1999a, 1999b; Baninasab and Rahemi, 2006; Lavee, 2007; Rosenstock et al., 2010; Goldschmidt, 2013; Sharma et al., 2015). Although this phenomenon is still not explained, different hypotheses have been reported. The alternate bearing in pistachio, as in all other fruit plants, is governed by both internal and external factors. The internal factors include the genotype and the endogenous hormone balance, whereas the external factors are the environmental conditions encountered by the pistachio tree (Mok and Mok, 2001; Foster et al., 2003; Achard et al., 2006; Al-Shdiefat and Qrunfleh, 2008; Bangerth, 2006; Dag et al., 2010; Gundesli et al., 2019). There are also other factors, such as planting density, irrigation and fertilisation, which may affect the growth and development of the plant (Weinbaum et al., 1994; Brown et al., 1995; Picchioni et al., 1997; Gundesli, 2017). Thus, floral development involves a large number of interwoven, well-defined growth, senescence and abscission processes. It is highly likely that plant growth regulators (PGRs) play distinct roles in the development of flowers, organs and functions. Accordingly, PGRs are thought to be among the most important causes of the activation of abscission zone and flower abscission (Aziz et al., 2001; Koshita and Takahara, 2004; GomezJimenez et al., 2010; Gundesli et al., 2019).

Since the discovery of PGRs, they have been used to manipulate plant growth and development. PGRs are active at micromolar or lower concentrations in the growth and development of plants. PGRs are classified into five 'classic' groups - abscisic acid, auxins, cytokinins (CKs), ethylene and gibberellins (Davies, 2004; George et al., 2008; Bons et al., 2015; Sharma et al., 2019). Among these groups, CKs, $\mathrm{N}^{6}$-substituted purine derivatives, are a significant class of PGRs that regulate a large number of physiological and developmental processes in plants. Numerous researchers have proved that the effects of CKs on both major and minor physiological processes are important throughout the development in the plant, from seed germination to leaf senescence, including photosynthesis and respiration (Ahmadi and Baker, 2000; Mok and Mok, 2001; George et al., 2008). The most common endogenous CK-free bases are isopentenyl adenine (iP), cis- and transzeatins $(c-\mathrm{Z}, t-\mathrm{Z})$ and dihydrozeatin (DHZ), which may occur in different metabolic forms (Ahmadi and Baker, 2000; Novak et al., 2003; Stirk et al., 2004). CKs control various processes in plant growth and development, such as the delay in senescence, the transmission of feeding signals or control in the balance of root/root growth (Kamada-Nobusada and Sakakiba, 2009).
Despite the richness of knowledge on the chemistry and physiology of CKs, the transition to molecular biology appears to be relatively slow and small compared with other plant hormones such as ethylene and gibberellins. In recent years, studies for CK receptors have begun to appear (Stirk et al., 2004; Novak et al., 2003). Although many metabolites have been identified, their importance and the regulation of metabolic transformations are still largely unknown. It has been reported that due to the transport of CK-like compounds to other organs, the species and concentrations of these compounds and also their functions showed differences in tissues between the plant organs (Wagner and Beck, 1993; Baktir et al., 2004; Davies, 2004). Palmer and Wong (1985) found 10 different CKs, including Z, ZR and DHZ. However, since the contribution of individual $\mathrm{CKs}$ to specific growth processes is unclear, the usefulness of $\mathrm{CK}$ amounts is open to interpretation. In short, CK research is important to solve many of the critical problems. A lot of information on the roles of endogenous CKs in fruit-bud abscission (alternate bearing) and embryo development in pistachio is still unknown. However, in recent years, a new approach to studying CKs has been developed. Therefore, in this study, major free-base endogenous CKs (Z, DHZ, iP) and their corresponding ribosides (ZR, DHZR, iPR) were determined using ultra-performance liquid chromatography-electrospray ionisation-tandem mass spectrometry (UPLC-ESIMS/MS) analysis. The objective of our research was to determine the levels of CKs in pistachio trees 35, 45, 55 and 65 days after full blooming (DAFB) to provide a complete CK profile during the critical stages of flower bud abscission and early embryo development.

\section{MATERIALS AND METHODS}

\section{Plant material}

Twelve adjacent, 33-year-old 'Uzun' pistachio trees (on $P$. vera Desf. rootstock, planted at $10 \times 10 \mathrm{~m}$ intervals) were selected for study in 2013 (an 'On' and 'Off' year). The trees were located in the Research and Experimental Area of the Ministry of Agriculture's Pistachio Research Institute of Gaziantep in Turkey.

\section{Characteristics of Uzun cultivar}

The tree structure is semi-erect and solid. It is one of the middle flowering cultivars with yellowish-green flowers. Bundle density is moderate, and division resistance is weak. Nut splitting rate was $69.34 \%$, and 100 grain weight was $110.69 \mathrm{~g}$. The inner fruit colour is green and a kind that is prone to absolute alternate bearing (Atli et al., 2003). This cultivar has chilling requirement of 550-600 chill units below $+7^{\circ} \mathrm{C}$. Moreover, the total temperature requirement is 3,797 degree-days of Gaziantep (Kuden et al., 1995). The artificial alternate bearing was provided by removing all flowers on three of the six 'Off' trees in April 2013 to ensure alternate bearing of both 'On' and 'Off' pistachio trees in the same season. Thereafter, the two groups of trees alternated in 
bearing habit until the completion of the study in 2015 . In this study, the shoots, leaves, panicles and nuts were sampled from 'On'-year and 'Off'-year trees (Figure 1). To better understand the results, climate data for the region was obtained from the General Directorate of Meteorology for 2015 (Table 1).

\section{Plant tissue sampling}

Samples were collected between 08:00 am and 10:00 am 35, 45, 55, and 65 DAFB in 2015 (Table 2). The sampling dates were selected based on previous studies (Gundesli, 2017), in which flower abscission layers were initiated 45 DAFB and were completed 55 DAFB in 'On'-year samples. The sampling period also coincided with the second phase of intense bud abscission that began 65 DAFB and increasing kernel development of the pistachio nut and bud abscission that also occurred in some 'Off'-year samples during this period. Therefore, the time before 65 DAFB was considered appropriate to be studied in this experiment. The experiment was designed as a randomised complete block with three replications and one tree per replication. For CK analysis,

Table 2. Sampling dates for analyses of CK-like compounds

\begin{tabular}{llr}
\hline & \multicolumn{2}{c}{ Plant parts } \\
\cline { 2 - 3 } & \multicolumn{2}{c}{$\begin{array}{c}\text { Shoots, leaves, flower buds, } \\
\text { panicles and nuts }\end{array}$} \\
\hline \multirow{3}{*}{ Physiological periods } & 35 DAFB & 15 May 2015 \\
& 45 DAFB & 25 May 2015 \\
& 55 DAFB & 04 June 2015 \\
& 65 DAFB & 14 June 2015 \\
\hline
\end{tabular}

DAFB, Days after full blooming, which was on 10 April 2015.

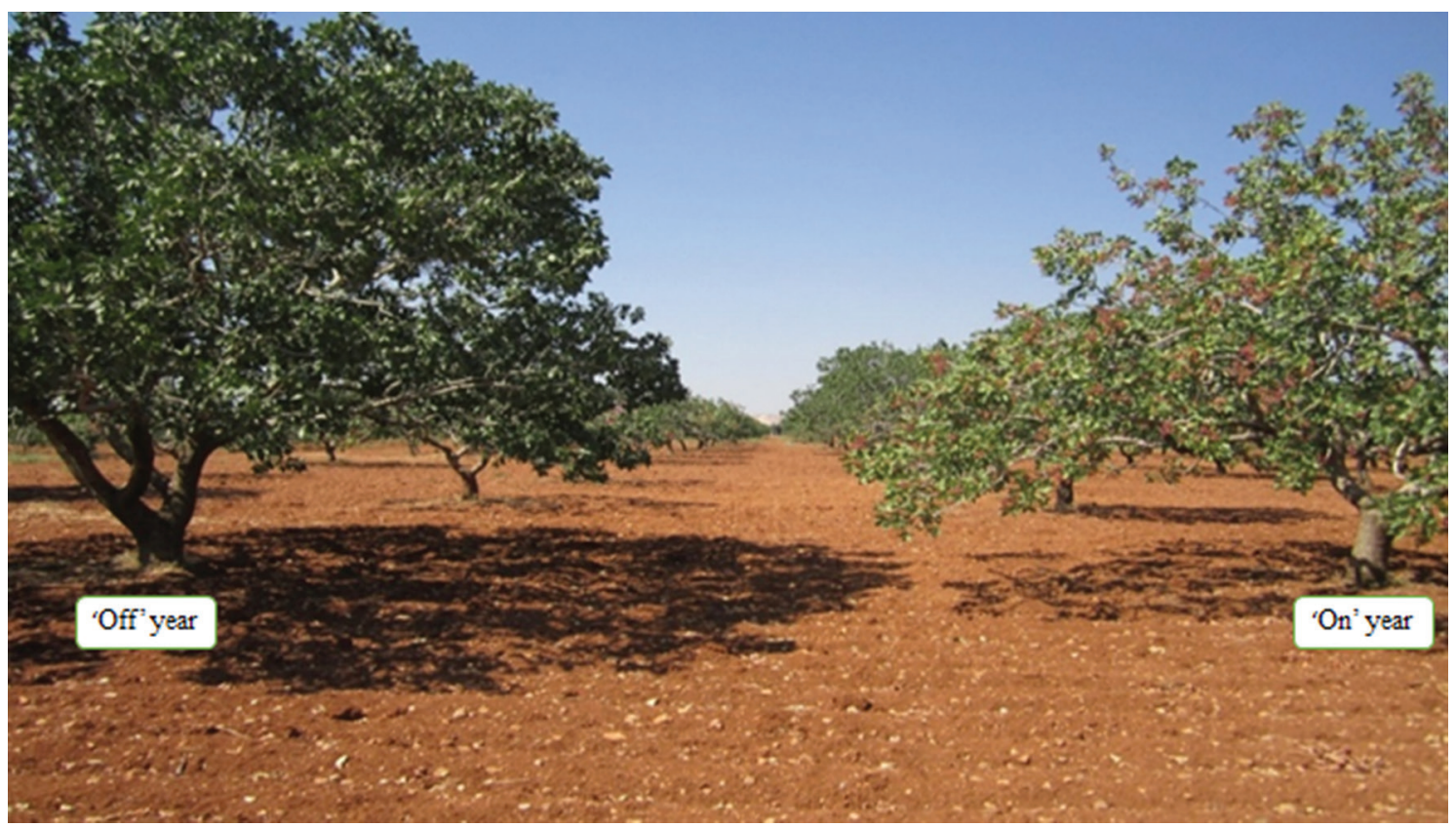

Figure 1. A view of the research pistachio orchard.

Table 1. Climate data for the Gaziantep Province of Turkey for 2015

\begin{tabular}{lccccc}
\hline Months & $\begin{array}{c}\text { Average monthly } \\
\text { temperature }\left({ }^{\circ} \mathrm{C}\right)\end{array}$ & $\begin{array}{c}\text { Monthly maximum } \\
\text { temperature }\left({ }^{\circ} \mathrm{C}\right)\end{array}$ & $\begin{array}{c}\text { Monthly minimum } \\
\text { temperature }\left({ }^{\circ} \mathrm{C}\right)\end{array}$ & $\begin{array}{c}\text { Monthly relative } \\
\text { humidity }(\%)\end{array}$ & $\begin{array}{c}\text { Average monthly } \\
\text { rainfall }(\mathrm{mm})\end{array}$ \\
\hline January & 3.8 & 16.1 & -6.0 & 72.3 & 105.8 \\
February & 5.3 & 15.5 & -1.7 & 78.3 & 174.4 \\
March & 9.0 & 22.3 & -0.1 & 64.5 & 95.4 \\
April & 12.6 & 27.5 & 3.8 & 55.4 & 33.1 \\
May & 19.7 & 33.3 & 8.7 & 44.9 & 35.5 \\
June & 23.7 & 33.5 & 13.7 & 41.7 & 1.1 \\
July & 29.3 & 40.7 & 19.2 & 30.1 & 11.3 \\
August & 28.8 & 39.6 & 18.4 & 35.8 & 5.3 \\
September & 26.8 & 38.6 & 16.3 & 32.8 & 11.2 \\
October & 18.4 & 29.9 & 9.7 & 58.3 & 54.6 \\
November & 11.1 & 22.4 & 2.2 & 51.7 & 21.8 \\
December & 6.4 & 18.8 & -1.3 & 50.9 & 51.2 \\
\hline Annual & 16.2 & 40.7 & -6.0 & 51.4 & 589.5 \\
\hline
\end{tabular}

Source: General Directorate of Meteorology in Turkey, 2015. 
five 1-year-old branches per four (north, south, east and west) directions of the canopy were sampled (totally 20 branches) and homogenised. Among them 10 shoots, 50 young leaves, 10 panicles, 30 flower buds and 30 nuts were selected accidentally and immediately transferred onto dry ice and then frozen in liquid nitrogen in the laboratory (Figure 2). The samples were rinsed with sterile distilled water to remove dust and soil, lyophilised using a lyophiliser (ilShin Freeze Dryers, FD-8518, Ede, The Netherlands), homogenised using a coffee grinder and stored at $+4^{\circ} \mathrm{C}$. Nut samples were homogenised as a whole, including the hull and embryo.

\section{Determination of CKs}

Quantification of CK-like compounds in different pistachio samples was conducted at the Plant Biotechnology Institute of the National Research Council of Canada using UPLC-ESI-MS/MS (http://www.nrcnrc.gc.ca/eng/solutions/advisory/plant_hormone.html) and deuterium-labelled internal standards, including the CKs c-Z, t-Z, cis- and trans-zeatin ribosides (c$\mathrm{ZR}, \mathrm{t}-\mathrm{ZR}$ ), cis- and trans-zeatin-O-glucosides (c-ZOG, $\mathrm{t}-\mathrm{ZOG}$ ), DHZ, DHZ riboside (DHZR), isopentenyl adenine (2iP) and isopentenyl adenosine riboside (iPR). The analysis was performed on a UPLC-ESI-MS/MS using a Waters ACQUITY UPLC system equipped with a binary solvent delivery manager and a sample manager coupled to a Waters Micromass Quattro Premier XE quadrupole tandem mass spectrometer via a Z-spray interface. MassLynx ${ }^{\mathrm{TM}}$ and QuanLynx ${ }^{\mathrm{TM}}$ (Micromass,
Manchester, UK) were used for data acquisition and data analysis (Chiwocha et al., 2003, 2005). The procedure used for the quantification of CKs in plant tissue was an improved procedure described in detail by Lulsdorf et al. $(2012,2013)$.

\section{Statistical analysis}

The data were analysed with JMP statistical software from SAS (Version 7) (SAS Institute Inc. Cary, NC, USA), and all the analytical values were the average of three replications. Significant differences were compared with the least significant differences (LSD) test executed at a $5 \%$ level of probability. The means \pm the standard error (SE) were calculated from three independent experiments and concentrations which are reported in $\mathrm{ng} \cdot \mathrm{g}^{-1}$ dry weight (DW).

\section{RESULTS}

\section{Identification and quantification of CK-like compounds}

\section{Concentration of CK-like compounds in shoot samples}

Significant differences $(p<0.05)$ in the concentration (ng $\cdot \mathrm{g}^{-1} \mathrm{DW}$ ) of the CK-like compounds between 'On'-year and 'Off'-year shoot samples of the 'Uzun' pistachio cultivar in different growth periods are shown in Table 3. The main CKs, expressed as a percentage of the total CK content, are shown in Figure 3. In total, six

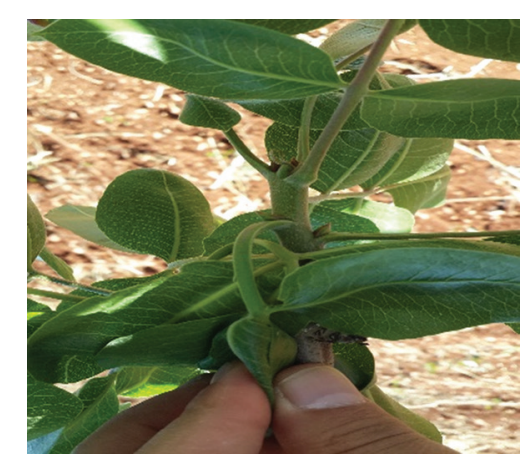

'On'-year leaf samples

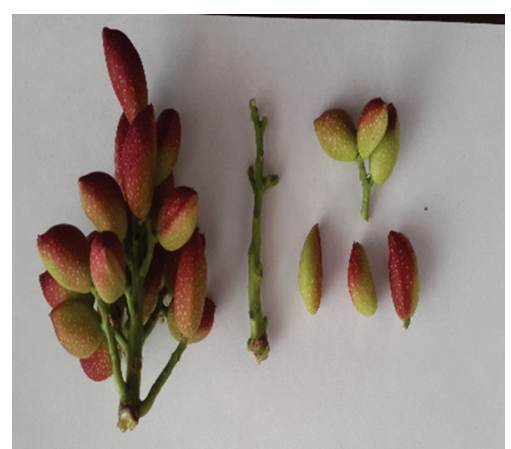

'On'-year panicle and nut samples

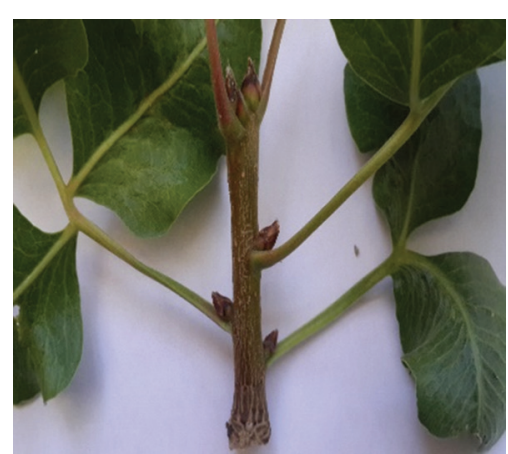

'On'-year flower bud and shoot samples

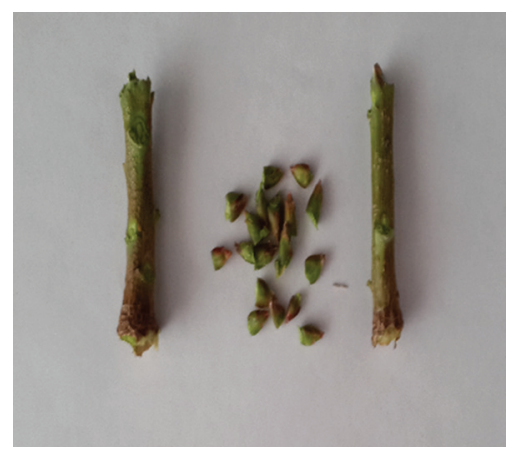

'Off'-year flower bud and shoot samples

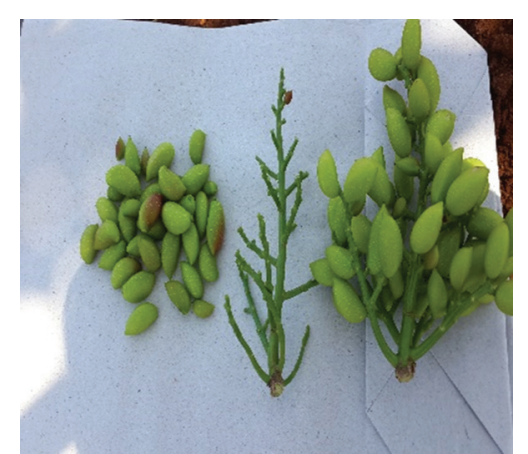

'On'-year panicle and nut samples

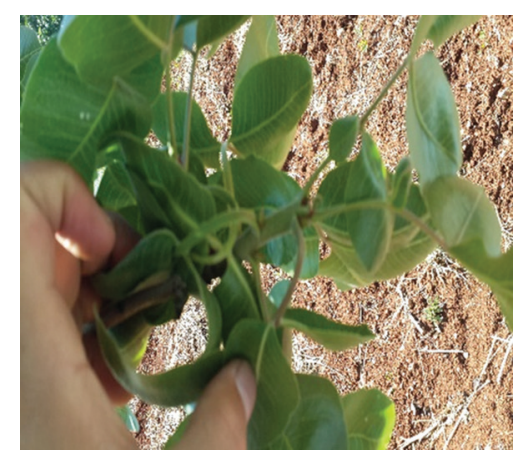

'Off'-year leaf samples

Figure 2. Appearance of the plant material used in the research. 
Table 3. Concentrations of CK-like compounds in the shoots in different physiological periods in 'On'- and 'Off'-year pistachio trees

\begin{tabular}{|c|c|c|c|c|c|c|c|c|}
\hline \multirow[t]{3}{*}{$\begin{array}{l}\text { Isoprenoid } \\
\text { CKs }\end{array}$} & \multicolumn{8}{|c|}{$\begin{array}{c}\text { Shoots } \\
\text { CK content }\left(\mathrm{ng} \cdot \mathrm{g}^{-1} \mathrm{DW}\right)\end{array}$} \\
\hline & \multicolumn{2}{|c|}{35 DAFB } & \multicolumn{2}{|c|}{45 DAFB } & \multicolumn{2}{|c|}{55 DAFB } & \multicolumn{2}{|c|}{65 DAFB } \\
\hline & 'Off' & 'On' & 'Off' & 'On' & 'Off' & 'On' & 'Off' & 'On' \\
\hline iP & $3.09^{\mathrm{a}} \pm 0.14$ & $2.20^{\mathrm{b}} \pm 0.10$ & $5.01 \pm 0.28$ & $4.95 \pm 0.25$ & $2.14^{\mathrm{a}} \pm 0.11$ & $7.19^{b} \pm 0.30$ & $6.94^{\mathrm{a}} \pm 0.35$ & $13.63^{b} \pm 0.60$ \\
\hline $\begin{array}{l}\text { D\%5 'On' } \times \\
\text { 'Off' year }\end{array}$ & \multicolumn{2}{|c|}{$0.25^{* *}$} & \multicolumn{2}{|c|}{0.58} & \multicolumn{2}{|c|}{$0.52^{* *}$} & \multicolumn{2}{|c|}{$1.13^{* *}$} \\
\hline iPR & $58.50 \pm 2.63$ & $54.70 \pm 2.46$ & $111.58^{a} \pm 6.15$ & $82.02^{b} \pm 4.10$ & $42.51^{b} \pm 2.13$ & $65.14^{\mathrm{a}} \pm 2.95$ & $25.33^{\mathrm{b}} \pm 1.21$ & $49.53^{a} \pm 2.28$ \\
\hline $\begin{array}{l}\mathrm{D} \% 5 \text { 'On' } \times \\
\text { 'Off' year }\end{array}$ & \multicolumn{2}{|c|}{5.75} & \multicolumn{2}{|c|}{$11.82 * *$} & \multicolumn{2}{|c|}{$5.76^{* *}$} & \multicolumn{2}{|c|}{$4.07 * *$} \\
\hline $\begin{array}{l}\text { Total iP } \\
\text { type }\end{array}$ & 61.59 & 56.90 & 116.59 & 86.97 & 44.65 & 72.33 & 32.27 & 63.16 \\
\hline$t-\mathrm{Z}$ & $1.27 \pm 0.05$ & $1.16 \pm 0.04$ & $1.18 \pm 0.02$ & $1.03 \pm 0.05$ & $<$ LOD & $<$ LOD & $<\mathrm{LOD}$ & $<\mathrm{LOD}$ \\
\hline $\begin{array}{l}\mathrm{D} \% 55^{\prime} \text { 'On' } \times \\
\text { 'Off' year }\end{array}$ & \multicolumn{2}{|c|}{0.13} & \multicolumn{2}{|c|}{0.09} & \multicolumn{2}{|c|}{-} & \multicolumn{2}{|c|}{-} \\
\hline \multirow[t]{2}{*}{$t-\mathrm{ZR}$} & $25.09^{b} \pm 1.13$ & $30.81^{\mathrm{a}} \pm 1.33$ & $13.35^{\mathrm{a}} \pm 0.70$ & $7.11^{\mathrm{b}} \pm 0.36$ & $12.69^{\mathrm{a}} \pm 0.60$ & $8.83^{b} \pm 0.38$ & $5.18^{\mathrm{a}} \pm 0.25$ & $3.07^{\mathrm{b}} \pm 0.13$ \\
\hline & \multicolumn{2}{|c|}{$2.86^{* *}$} & \multicolumn{2}{|c|}{$1.30^{* *}$} & \multicolumn{2}{|c|}{$1.19^{* *}$} & \multicolumn{2}{|c|}{$0.44^{* *}$} \\
\hline$t-\mathrm{ZOG}$ & $24.58^{a} \pm 1.10$ & $32.24^{b} \pm 1.45$ & $16.67^{\mathrm{a}} \pm 0.92$ & $15.34^{b} \pm 0.77$ & $15.83^{b} \pm 0.69$ & $17.06^{\mathrm{a}} \pm 0.77$ & $9.60^{b} \pm 0.45$ & $20.85^{\mathrm{a}} \pm 0.91$ \\
\hline $\begin{array}{l}\text { D\%5 'On' } \times \\
\text { 'Off' year }\end{array}$ & \multicolumn{2}{|c|}{$2.91^{* *}$} & \multicolumn{2}{|c|}{1.92} & \multicolumn{2}{|c|}{1.74} & \multicolumn{2}{|c|}{$1.68^{* *}$} \\
\hline$c-\mathrm{ZR}$ & $3.13^{b} \pm 0.12$ & $3.42^{\mathrm{a}} \pm 0.15$ & $4.44 \pm 0.20$ & $4.52 \pm 0.21$ & $2.01^{b} \pm 0.09$ & $2.28^{\mathrm{a}} \pm 0.15$ & $1.96^{\mathrm{a}} \pm 0.10$ & $1.50^{\mathrm{b}} \pm 0.06$ \\
\hline $\begin{array}{l}\text { D\%5 'On' } \times \\
\text { 'Off' year }\end{array}$ & \multicolumn{2}{|c|}{$0.27^{* *}$} & \multicolumn{2}{|c|}{0.52} & \multicolumn{2}{|c|}{$0.22^{* *}$} & \multicolumn{2}{|c|}{$0.16^{* *}$} \\
\hline$c-Z$ & nd & $<\mathrm{LOD}$ & nd & nd & nd & nd & nd & $<\mathrm{LOD}$ \\
\hline$c-\mathrm{ZOG}$ & nd & $<\mathrm{LOD}$ & nd & nd & nd & nd & $<\mathrm{LOD}$ & nd \\
\hline Total Z type & 54.07 & 67.63 & 35.64 & 26.97 & 31.81 & 28.17 & 16.74 & 25.42 \\
\hline DHZ & nd & nd & nd & nd & nd & nd & nd & nd \\
\hline DHZR & $<\mathrm{LOD}$ & $<\mathrm{LOD}$ & $<\mathrm{LOD}$ & $<\mathrm{LOD}$ & $<\mathrm{LOD}$ & $<\mathrm{LOD}$ & $<\mathrm{LOD}$ & $<\mathrm{LOD}$ \\
\hline $\begin{array}{l}\text { Total DHZ } \\
\text { type }\end{array}$ & $<\mathrm{LOD}$ & $<\mathrm{LOD}$ & $<\mathrm{LOD}$ & $<\mathrm{LOD}$ & $<\mathrm{LOD}$ & $<\mathrm{LOD}$ & $<\mathrm{LOD}$ & $<\mathrm{LOD}$ \\
\hline $\begin{array}{l}\text { Total } \\
\text { isoprenoid } \\
\text { CKs } \\
\end{array}$ & 115.66 & 124.53 & 152.23 & 113.94 & 76.46 & 100.5 & 49.01 & 88.58 \\
\hline
\end{tabular}

No DHZ was detected in any of the samples. The results represent mean \pm standard error. $<$ LOD, below the limit of detection; nd, not detected. Different letters show statistically different levels. ${ }^{*} p<0.05 ; * * p>0.01$.

For other explanation, see Table 2.

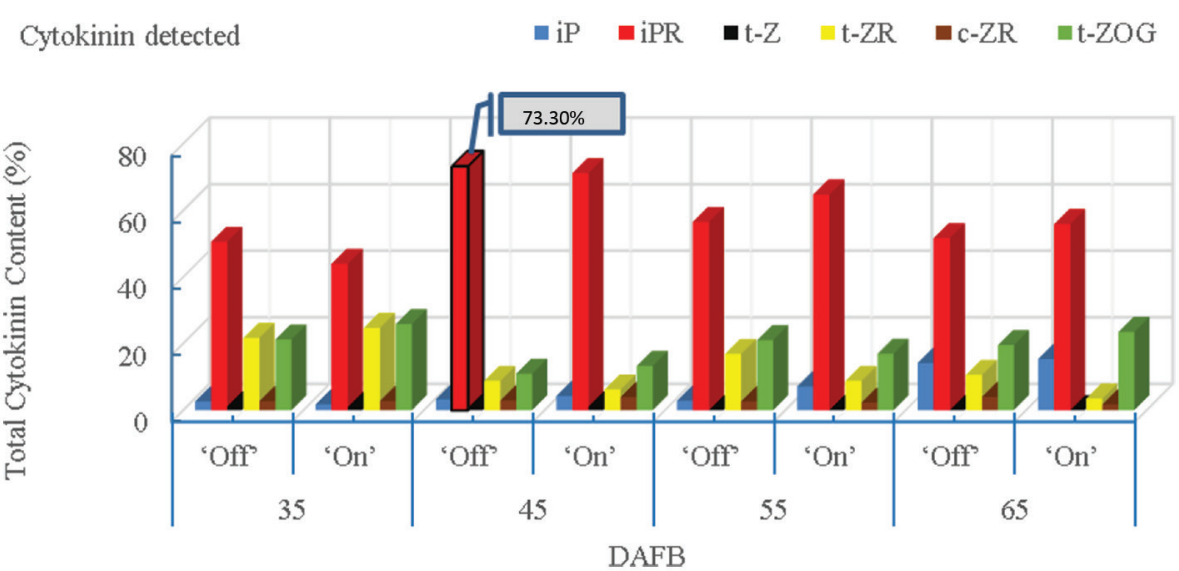

Figure 3. The main CK-like compounds detected in the shoots of 'On'- and 'Off'-year pistachio trees as a percentage of the total CK content. Percentages were calculated using the formula: each CK compound content $\times 100 /$ total CK content. DAFB, days after full blooming. 
CKs were detected in the shoots. There were irregular and different tendencies in different physiological periods in 'On'-year and 'Off'-year trees, especially when the concentrations of the compounds $t$-ZOG, $t$-ZR and $c$-ZR were high in the early stages of full bloom and gradually decreased until 65 DAFB when flower abscission severity was at the minimum level. Among the CKs, iPR (25.33-111.58 $\mathrm{ng} \cdot \mathrm{g}^{-1} \mathrm{DW}$ in 'Off' year; 49.53-82.02 $\mathrm{ng} \cdot \mathrm{g}^{-1} \mathrm{DW}$ in 'On' year) was the main isoprenoid $\mathrm{CK}$; as the dominant conjugate, it showed the highest values (maximum at $45 \mathrm{DAFB}$ ), contributing over $70 \%$ of the total CK content (Figure 3 ). In contrast, $c$-ZR (1.96-4.44 ng . $\mathrm{g}^{-1} \mathrm{DW}$ in 'Off' year; 1.50$4.52 \mathrm{ng} \cdot \mathrm{g}^{-1} \mathrm{DW}$ in 'On' year) was found to have the lowest values (Table 3). It was determined in this study that the iPR level in the shoots was low in May in the first period of full flowering and then reached its maximum value in July 45 days after full flowering (when flower bud abscission was heavy). However, the values of other CKs (t-ZOG, $t$-ZR, $c$-ZR) were high 35 days after full flowering, followed by a gradual decrease in the bud abscission period during kernel development. It was determined that 'On'-year trees had mostly higher total CK content in the shoots than 'Off'-year trees (Table 3 and Figure 3). It was determined that the concentrations of the CKs $t$-ZOG, $t$-ZR, $c$-ZR and iPR were higher in the shoots than leaves. Although $t$-ZR was not found in the leaves and flower buds, it was detected in shoot samples. Moreover, $c-Z$ was found to be below the detection limit and DHZ could not be detected in shoot samples (Table 3).

\section{Concentration of CK-like compounds in leaf samples}

Significant differences $(p<0.05)$ in the concentration (ng $\left.\cdot \mathrm{g}^{-1} \mathrm{DW}\right)$ of the CK-like compounds between 'On'-year and 'Off'-year leaf samples of the 'Uzun' pistachio cultivar in different growth periods are shown in Table 4. The main CKs, expressed as a percentage of the total $\mathrm{CK}$ content, are shown in

Table 4. Concentrations of CK-like compounds in the leaves in different physiological periods in 'On'- and 'Off'-year pistachio trees

\begin{tabular}{|c|c|c|c|c|c|c|c|c|}
\hline \multirow[t]{3}{*}{$\begin{array}{l}\text { Isoprenoid } \\
\text { CK s }\end{array}$} & \multicolumn{8}{|c|}{$\begin{array}{c}\text { Leaves } \\
\text { CK content }\left(\mathrm{ng} \cdot \mathrm{g}^{-1} \mathrm{DW}\right)\end{array}$} \\
\hline & \multicolumn{2}{|c|}{35 DAFB } & \multicolumn{2}{|c|}{45 DAFB } & \multicolumn{2}{|c|}{55 DAFB } & \multicolumn{2}{|c|}{65 DAFB } \\
\hline & 'Off' & 'On' & 'Off' & 'On' & 'Off' & 'On' & 'Off' & 'On' \\
\hline iP & $21.85^{\mathrm{b}} \pm 0.98$ & $27.55^{\mathrm{a}} \pm 1.24$ & $22.89^{a} \pm 1.03$ & $12.85^{\mathrm{b}} \pm 0.58$ & $12.72^{\mathrm{a}} \pm 0.51$ & $7.66^{\mathrm{b}} \pm 0.34$ & $22.39^{\mathrm{a}} \pm 1.01$ & $16.09^{\mathrm{b}} \pm 0.70$ \\
\hline $\begin{array}{l}\mathrm{D} \% 5 \text { 'On' } \times \\
\text { 'Off' year }\end{array}$ & \multicolumn{2}{|c|}{$2.52^{* *}$} & \multicolumn{2}{|c|}{$1.88^{* *}$} & \multicolumn{2}{|c|}{$0.99^{* \prime}$} & \multicolumn{2}{|c|}{$1.97^{* *}$} \\
\hline iPR & $18.95 \pm 0.80$ & $21.78 \pm 0.99$ & $35.34 \pm 1.51$ & $20.54 \pm 0.92$ & $42.75 \pm 1.70$ & $23.08 \pm 1.05$ & $24.32 \pm 1.10$ & $23.52 \pm 1.04$ \\
\hline $\begin{array}{l}\mathrm{D} \% 55^{\prime} \text { 'On' } \times \\
\text { 'Off' year }\end{array}$ & \multicolumn{2}{|c|}{$2.07^{* *}$} & \multicolumn{2}{|c|}{$2.93^{* *}$} & \multicolumn{2}{|c|}{$3.19^{* *}$} & \multicolumn{2}{|c|}{2.43} \\
\hline Total iP type & 40.8 & 49.33 & 58.23 & 33.39 & 55.47 & 30.74 & 46.71 & 39.61 \\
\hline$t-Z$ & $<\mathrm{LOD}$ & $<\mathrm{LOD}$ & nd & nd & nd & nd & nd & nd \\
\hline$c-Z$ & nd & nd & nd & nd & nd & nd & nd & nd \\
\hline$t$-ZR & $3.52 \pm 0.16$ & $1.98 \pm 0.08$ & $1.70 \pm 0.06$ & $2.01 \pm 0.09$ & $1.23 \pm 0.06$ & $1.22 \pm 0.05$ & $1.06 \pm 0.04$ & $1.13 \pm 0.04$ \\
\hline $\begin{array}{l}\text { D\%5 'On' } \times \\
\text { 'Off' year }\end{array}$ & \multicolumn{2}{|c|}{$0.27^{* *}$} & \multicolumn{2}{|c|}{$0.16^{* *}$} & \multicolumn{2}{|c|}{0.11} & \multicolumn{2}{|c|}{0.09} \\
\hline$c-\mathrm{ZR}$ & $1.29 \pm 0.07$ & $1.19 \pm 0.05$ & $1.20^{\mathrm{a}} \pm 0.06$ & $1.07^{\mathrm{b}} \pm 0.04$ & $<\mathrm{LOD}$ & $<\mathrm{LOD}$ & $<\mathrm{LOD}$ & $<\mathrm{LOD}$ \\
\hline $\begin{array}{l}\mathrm{D} \% 5 \text { 'On' } \times \\
\text { 'Off' year }\end{array}$ & \multicolumn{2}{|c|}{0.12} & \multicolumn{2}{|c|}{$0.11^{* *}$} & \multicolumn{2}{|c|}{-} & \multicolumn{2}{|c|}{-} \\
\hline$t-\mathrm{ZOG}$ & $5.12^{\mathrm{a}} \pm 0.23$ & $4.37^{b} \pm 0.20$ & $3.17^{b} \pm 0.14$ & $6.08^{\mathrm{a}} \pm 0.27$ & $2.05 \pm 0.10$ & $2.00 \pm 0.8$ & $6.66^{a} \pm 0.30$ & $5.07^{b} \pm 0.22$ \\
\hline $\begin{array}{l}\mathrm{D} \% 5 \text { 'On' } \times \\
\text { 'Off' year }\end{array}$ & \multicolumn{2}{|c|}{$0.41^{* *}$} & \multicolumn{2}{|c|}{$0.47^{* *}$} & \multicolumn{2}{|c|}{0.19} & \multicolumn{2}{|c|}{$0.60^{* *}$} \\
\hline$c-\mathrm{ZOG}$ & nd & nd & $<\mathrm{LOD}$ & nd & $<\mathrm{LOD}$ & nd & nd & nd \\
\hline Total Z type & 9.93 & 7.54 & 6.07 & 9.16 & 3.28 & 3.22 & 7.72 & 6.20 \\
\hline $\mathrm{DHZ}$ & nd & nd & nd & nd & nd & nd & nd & nd \\
\hline DHZR & $<\mathrm{LOD}$ & nd & nd & nd & nd & $<\mathrm{LOD}$ & $<\mathrm{LOD}$ & $<\mathrm{LOD}$ \\
\hline $\begin{array}{l}\text { Total DHZ- } \\
\text { type }\end{array}$ & $<\mathrm{LOD}$ & nd & nd & nd & nd & $<\mathrm{LOD}$ & $<\mathrm{LOD}$ & $<\mathrm{LOD}$ \\
\hline $\begin{array}{l}\text { Total } \\
\text { isoprenoid } \\
\text { CKs }\end{array}$ & 50.73 & 56.87 & 64.3 & 42.55 & 58.75 & 33.96 & 54.43 & 45.81 \\
\hline
\end{tabular}


Cytokinin detected $\quad \square \mathrm{iP}=\mathrm{iPR} \backsim \mathrm{t}-\mathrm{ZR}=\mathrm{c}-\mathrm{ZR} \backsim \mathrm{t}-\mathrm{ZOG}$

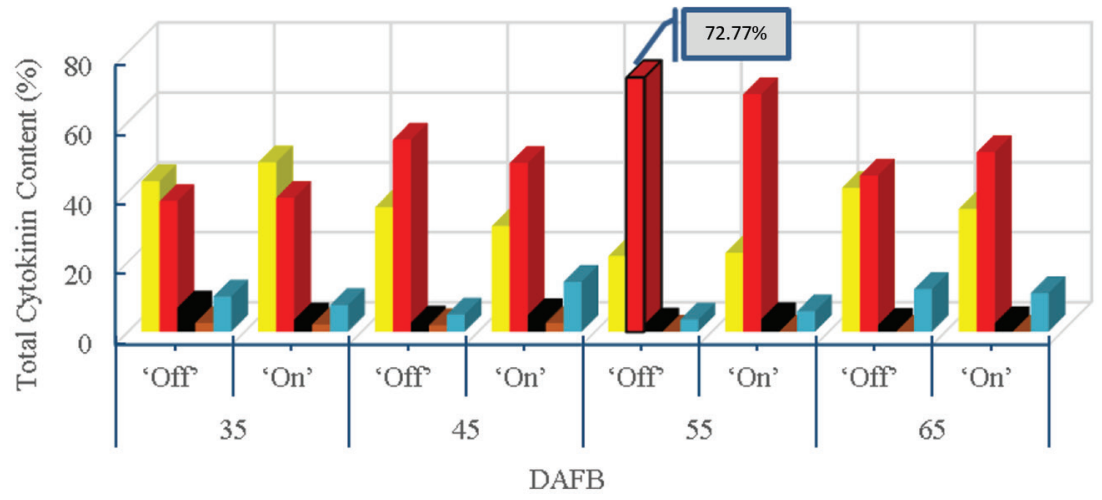

Figure 4. The main CK-like compounds detected in the leaves of 'On'- and 'Off'-year pistachio trees as a percentage of the total CK content. For explanation, see Figure 3.

Figure 4. In total, five CKs were detected in the leaves. It was observed that there were irregular and different tendencies in different physiological periods in 'On'-year and 'Off'-year trees (Figure 4). Among the CKs, iPR (18.95-42.75 $\mathrm{ng} \cdot \mathrm{g}^{-1} \mathrm{DW}$ in 'Off' year; 20.54-23.52 ng $\cdot \mathrm{g}^{-1} \mathrm{DW}$ in 'On' year), contributing over $70 \%$ of the total $\mathrm{CK}$ content, and iP (12.72$22.89 \mathrm{ng} \cdot \mathrm{g}^{-1} \mathrm{DW}$ in 'Off' year; 7.66-27.55 $\mathrm{ng} \cdot \mathrm{g}^{-1}$ DW in 'On' year) were the main isoprenoid CKs, as the dominant conjugates showing the highest values. In contrast, $c$-ZR $\left(1.20-1.29 \mathrm{ng} \cdot \mathrm{g}^{-1} \mathrm{DW}\right.$ in 'Off' year; 1.07-1.19 ng . $\mathrm{g}^{-1} \mathrm{DW}$ in 'On' year) was found to have the lowest values (Table 4). In the research, it was determined that in the first period of full flowering (35 DAFB), the levels of iPR and iP were low; then 55 days after full flowering, they reached the maximum values until July (when flower bud abscission was heavy) and then decreased (Table 4 and Figure 4). It was determined that the CK concentrations in the leaves of 'Off'-year trees were higher than in the leaves of 'On'-year trees (Table 4). In leaf samples, $c$-ZR and DHZR were found to be below the detection limit, and $c-Z$ and DHZ could not be detected. $t$-Z was not detected in leaf samples, but it was detected in shoot samples (Table 4).

\section{Concentration of CK-like compounds in flower bud samples}

Significant differences $(p<0.05)$ in the concentration (ng $\cdot \mathrm{g}^{-1} \mathrm{DW}$ ) of the CK-like compounds between 'On'year and 'Off'-year flower bud samples of the 'Uzun' pistachio cultivar in different growth periods are shown in Table 5. The main CKs, expressed as a percentage of the total CK content, are shown in Figure 5. In total, five CKs were detected in the flower buds. There were similar trends in different physiological periods in 'On'-year and 'Off'-year trees, but there were different changes in some CKs (Figure 5). Among the CKs, iPR (14.82-56.60 ng . $\mathrm{g}^{-1} \mathrm{DW}$ in 'Off' year; $12.41-$ $53.86 \mathrm{ng} \cdot \mathrm{g}^{-1} \mathrm{DW}$ in 'On' year), contributing over $75 \%$ of the total CK content, and iP (2.02-15.76 $\mathrm{ng} \cdot \mathrm{g}^{-1} \mathrm{DW}$ in 'Off' year; 1.11-12.47 ng · $\mathrm{g}^{-1} \mathrm{DW}$ in 'On' year) were the main isoprenoid $\mathrm{CKs}$, as the dominant conjugates showing the highest values; $c$-ZR $\left(1.18-1.61 \mathrm{ng} \cdot \mathrm{g}^{-1}\right.$ DW in 'Off' year; $1.62-3.87 \mathrm{ng} \cdot \mathrm{g}^{-1} \mathrm{DW}$ in 'On' year) was found to have the lowest values (Table 5). It was determined that the levels of iPR and iP in the early periods of full flowering (May) were low in both 'On' and 'Off' years, but later they were higher and reached the maximum values 65 DAFB (when flower bud abscission was heavy) (Table 4 and Figure 5). It was determined that the flower buds of 'On'-year trees had higher concentrations of CK-like compounds than 'Off'-year trees (Table 5). According to the results, the iP and iPR concentrations were lower in the flower buds than in the leaves and shoots. In flower bud samples, DHZR concentrations were found to be below the detection limit and $c-Z O G, c-Z$ and DHZ could not be detected (Table 5).

\section{Concentration of CK-like compounds in panicle samples}

The concentrations (ng $\cdot \mathrm{g}^{-1} \mathrm{DW}$ ) of the CK-like compounds for the pistachio panicles of only 'On'year trees of the 'Uzun' pistachio cultivar are shown in Table 6. The CK concentrations in the panicles at different growth stages were significant at $p<0.05$. The main CKs, expressed as a percentage of the total $\mathrm{CK}$ content, are shown in Figure 6. In total, seven CKs were detected in the panicles (Table 6). Among the CKs, iPR (58.36-105.31 ng $\cdot \mathrm{g}^{-1} \mathrm{DW}$ in 'On' year), contributing over $80 \%$ of the total CK content, and $t$-ZOG (6.53-29.22 in 'On' year) were dominant and showed the highest values; DHZR $\left(1.10 \mathrm{ng} \cdot \mathrm{g}^{-1}\right)$ and $c$-ZOG $\left(2.38-2.76 \mathrm{ng} \cdot \mathrm{g}^{-1}\right.$ in 'On' year) were found to have the lowest values (Table 6). It was determined that after a decrease in the levels of total isoprenoid CKs in the panicles 35 DAFB (end of May), its concentration reached the maximum values 45 DAFB (during heavy flower bud abscission) and subsequently decreased. However, $t-Z O G, t-Z R$ and $c$-ZR levels were high 35 DAFB and then decreased. 
Table 5. Concentrations of CK-like compounds in the flower buds in different physiological periods in 'On'- and 'Off'-year pistachio trees

\begin{tabular}{|c|c|c|c|c|c|c|c|c|}
\hline \multirow{4}{*}{$\begin{array}{l}\text { Isoprenoid } \\
\text { CKs }\end{array}$} & \multicolumn{8}{|c|}{ Flower buds } \\
\hline & \multicolumn{8}{|c|}{$\mathrm{CK}$ content $\left(\mathrm{ng} \cdot \mathrm{g}^{-1} \mathrm{DW}\right)$} \\
\hline & \multicolumn{2}{|c|}{35 DAFB } & \multicolumn{2}{|c|}{45 DAFB } & \multicolumn{2}{|c|}{55 DAFB } & \multicolumn{2}{|c|}{65 DAFB } \\
\hline & 'Off' & 'On' & 'Off' & 'On' & 'Off' & 'On' & 'Off' & 'On' \\
\hline iP & $2.02 \pm 0.10$ & $1.11 \pm 0.06$ & $4.01^{\mathrm{a}} \pm 0.18$ & $2.90^{\mathrm{b}} \pm 0.13$ & $3.06^{\mathrm{b}} \pm 0.11$ & $6.60^{\mathrm{a}} \pm 0.30$ & $15.76^{\mathrm{a}} \pm 0.61$ & $12.47^{\mathrm{b}} \pm 0.50$ \\
\hline $\begin{array}{l}\text { D\%5 'On' } \times \\
\text { 'Off' year }\end{array}$ & \multicolumn{2}{|c|}{0.17} & \multicolumn{2}{|c|}{$0.33^{* *}$} & \multicolumn{2}{|c|}{$0.52^{* *}$} & \multicolumn{2}{|c|}{$1.27^{* *}$} \\
\hline iPR & $14.82^{\mathrm{a}} \pm 0.67$ & $12.41^{\mathrm{b}} \pm 0.62$ & $26.18^{\mathrm{b}} \pm 1.14$ & $30.19^{\mathrm{a}} \pm 1.36$ & $18.74^{b} \pm 0.66$ & $37.13^{\mathrm{a}} \pm 1.65$ & $56.60 \pm 2.20$ & $53.86 \pm 2.10$ \\
\hline $\begin{array}{l}\mathrm{D} \% 5 \text { 'On' } \times \\
\text { 'Off' year }\end{array}$ & \multicolumn{2}{|c|}{$1.44^{* *}$} & \multicolumn{2}{|c|}{$2.85^{* *}$} & \multicolumn{2}{|c|}{$2.99^{* *}$} & \multicolumn{2}{|c|}{4.98} \\
\hline $\begin{array}{l}\text { Total iP } \\
\text { type }\end{array}$ & $16.84^{\mathrm{a}}$ & $13.52^{\mathrm{b}}$ & $30.19^{\mathrm{b}}$ & $33.09^{\mathrm{a}}$ & $21.8^{\mathrm{b}}$ & $43.73^{\mathrm{a}}$ & $72.36^{\mathrm{a}}$ & $66.33^{\mathrm{b}}$ \\
\hline$t-\mathrm{ZOG}$ & $6.46 \pm 0.29$ & $7.63 \pm 0.38$ & $4.26 \pm 0.20$ & $7.15 \pm 0.22$ & $3.24 \pm 0.17$ & $4.54 \pm 0.24$ & $2.12 \pm 0.08$ & $3.98 \pm 0.18$ \\
\hline $\begin{array}{l}\text { D\%5 'On' } \times \\
\text { 'Off' year }\end{array}$ & \multicolumn{2}{|c|}{$0.74^{* *}$} & \multicolumn{2}{|c|}{$0.58^{* *}$} & \multicolumn{2}{|c|}{$0.38^{* *}$} & \multicolumn{2}{|c|}{$0.27^{* *}$} \\
\hline$c-\mathrm{ZOG}$ & nd & nd & nd & nd & nd & nd & nd & nd \\
\hline$t-Z$ & $<\mathrm{LOD}$ & nd & nd & $<\mathrm{LOD}$ & nd & nd & nd & nd \\
\hline$c-Z$ & nd & nd & nd & nd & nd & nd & nd & nd \\
\hline$t-\mathrm{ZR}$ & $5.20 \pm 0.18$ & $5.26 \pm 0.25$ & $1.95^{\mathrm{b}} \pm 0.11$ & $2.59^{\mathrm{a}} \pm 0.13$ & $3.02^{\mathrm{a}} \pm 0.18$ & $2.06^{b} \pm 0.08$ & $3.15^{b} \pm 0.14$ & $3.76^{\mathrm{a}} \pm 0.20$ \\
\hline $\begin{array}{l}\mathrm{D} \% 5 \text { 'On' } \times \\
\text { 'Off' year }\end{array}$ & \multicolumn{2}{|c|}{0.50} & \multicolumn{2}{|c|}{$0.22^{* *}$} & \multicolumn{2}{|c|}{$0.25^{* *}$} & \multicolumn{2}{|c|}{$0.33^{* *}$} \\
\hline$c-\mathrm{ZR}$ & $1.53 \pm 0.07$ & $1.62 \pm 0.09$ & $1.61^{b} \pm 0.08$ & $2.34^{\mathrm{a}} \pm 0.11$ & $1.18^{b} \pm 0.05$ & $1.65^{\mathrm{a}} \pm 0.14$ & $1.23^{b} \pm 0.06$ & $3.87^{a} \pm 0.15$ \\
\hline $\begin{array}{l}\text { D\%5 'On' } \times \\
\text { 'Off' year }\end{array}$ & \multicolumn{2}{|c|}{0.16} & \multicolumn{2}{|c|}{$0.19^{* *}$} & \multicolumn{2}{|c|}{$0.13^{* *}$} & \multicolumn{2}{|c|}{$0.24^{* *}$} \\
\hline Total Z-type & 13.19 & 14.51 & 7.82 & 12.08 & 7.44 & 8.25 & 6.5 & 12.75 \\
\hline DHZ & nd & nd & nd & nd & nd & nd & nd & nd \\
\hline DHZR & $<\mathrm{LOD}$ & $<\mathrm{LOD}$ & $<\mathrm{LOD}$ & $<\mathrm{LOD}$ & $<\mathrm{LOD}$ & $<\mathrm{LOD}$ & $<\mathrm{LOD}$ & $<$ LOD \\
\hline $\begin{array}{l}\text { Total DHZ } \\
\text { type }\end{array}$ & $<\mathrm{LOD}$ & $<\mathrm{LOD}$ & $<\mathrm{LOD}$ & $<\mathrm{LOD}$ & $<\mathrm{LOD}$ & $<\mathrm{LOD}$ & $<\mathrm{LOD}$ & $<\mathrm{LOD}$ \\
\hline $\begin{array}{l}\text { Total } \\
\text { isoprenoid } \\
\text { CK s } \\
\end{array}$ & 30.03 & 28.03 & 38.01 & 45.17 & 29.24 & 51.98 & 78.86 & 79.08 \\
\hline
\end{tabular}

No $c$-Z, $c$-ZOG or DHZ were detected in any of the samples. The results represent mean \pm standard error. $<$ LOD, below the limit of detection; nd, not detected. Different letters show statistically different levels. ${ }^{*} p<0.05 ; * *>0.01$.

For explanation, see Table 3.

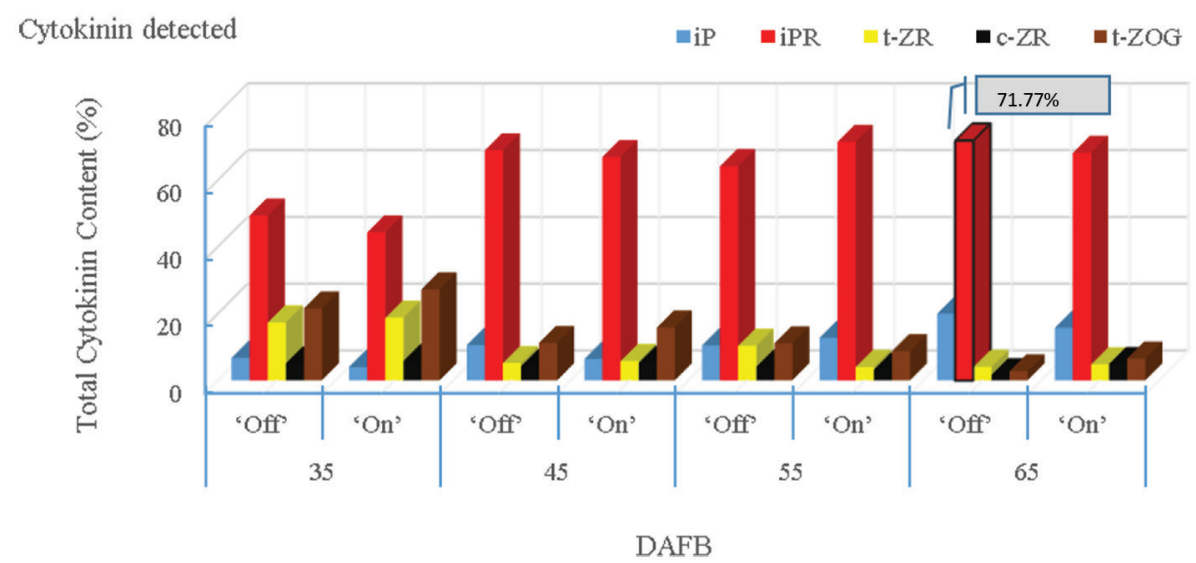

Figure 5. The main CK-like compounds detected in the flower buds of 'On' and 'Off'-year pistachio trees as a percentage of the total CK content. For explanations, see Figure 3.

The concentrations of CKs (such as iPR) in the panicles were found to be higher than in the other organs (leaves, shoots, flower buds and fruit) (Table 6 and Figure 6). DHZR was found to be mostly below the detection limit in panicle samples, and $t-Z, c-Z$ and DHZ could not be detected (Table 6). 
Table 6. Concentrations of CK -like compounds in the panicles in different physiological periods in only 'On'-year pistachio trees

\begin{tabular}{|c|c|c|c|c|c|c|}
\hline \multicolumn{7}{|c|}{$\begin{array}{c}\text { Panicles } \\
\text { CK content }\left(\mathrm{ng} \cdot \mathrm{g}^{-1} \mathrm{DW}\right) \\
\text { 'On' year }\end{array}$} \\
\hline & 35 DAFB & 45 DAFB & 55 DAFB & 65 DAFB & $\begin{array}{c}\text { Period } \\
\text { average }\end{array}$ & $\begin{array}{c}\text { D\%5 periods } \times \\
\text { 'On' year }\end{array}$ \\
\hline iP & $3.27^{\mathrm{c}} \pm 0.19$ & $7.69^{b} \pm 0.26$ & $7.88^{\mathrm{b}} \pm 0.18$ & $13.34^{\mathrm{a}} \pm 0.21$ & 8.05 & $0.71^{* *}$ \\
\hline iPR & $60.47^{c} \pm 0.30$ & $105.31^{\mathrm{a}} \pm 1.01$ & $78.78^{b} \pm 0.28$ & $58.36^{\mathrm{c}} \pm 0.20$ & 75.73 & $6.09^{* *}$ \\
\hline Total iP type & 63.74 & 113 & 86.66 & 71.7 & & \\
\hline$t-\mathrm{ZOG}$ & $29.22^{\mathrm{a}} \pm 1.31$ & $6.53^{b} \pm 0.26$ & $6.95^{b} \pm 0.29$ & $6.99^{b} \pm 0.33$ & 12.42 & $1.31^{* *}$ \\
\hline$c-Z O G$ & $2.27^{\mathrm{c}} \pm 0.10$ & $2.51^{b} \pm 0.18$ & $2.38^{\mathrm{bc}} \pm 0.09$ & $2.76^{\mathrm{a}} \pm 0.17$ & & $0.18^{* *}$ \\
\hline$t-Z$ & nd & nd & nd & nd & & - \\
\hline$c-Z$ & nd & nd & nd & nd & & - \\
\hline$t$-ZR & $12.24^{\mathrm{a}} \pm 0.55$ & $3.90^{\mathrm{b}} \pm 0.21$ & $2.99^{c} \pm 0.13$ & $2.06^{\mathrm{d}} \pm 0.09$ & 2.48 & $0.55^{* *}$ \\
\hline$c-\mathrm{ZR}$ & $5.44^{a} \pm 0.25$ & $4.20^{b} \pm 0.19$ & $4.00^{b} \pm 0.16$ & $1.66^{c} \pm 0.07$ & 3.82 & $0.32^{* *}$ \\
\hline Total Z type & 50.27 & 17.14 & 16.32 & 13.47 & & \\
\hline DHZ & nd & nd & nd & nd & & - \\
\hline DHZR & $1.10 \pm 0.05$ & $<\mathrm{LOD}$ & $<\mathrm{LOD}$ & $<\mathrm{LOD}$ & & \\
\hline Total DHZ type & 1.10 & $<\mathrm{LOD}$ & $<\mathrm{LOD}$ & $<\mathrm{LOD}$ & & \\
\hline Total isoprenoid CKs & 114.01 & 130.14 & 102.98 & 85.17 & & \\
\hline
\end{tabular}

No $t$-Z. $c$-Z or DHZ were detected in any of the samples. The results represent mean \pm standard error. $<$ LOD, below the limit of detection; nd, not detected. Different letters show statistically different levels. ${ }^{*} p<0.05 ; * * p 0.01$.

For explanation, see Table 3.

\section{Cytokinin detected}

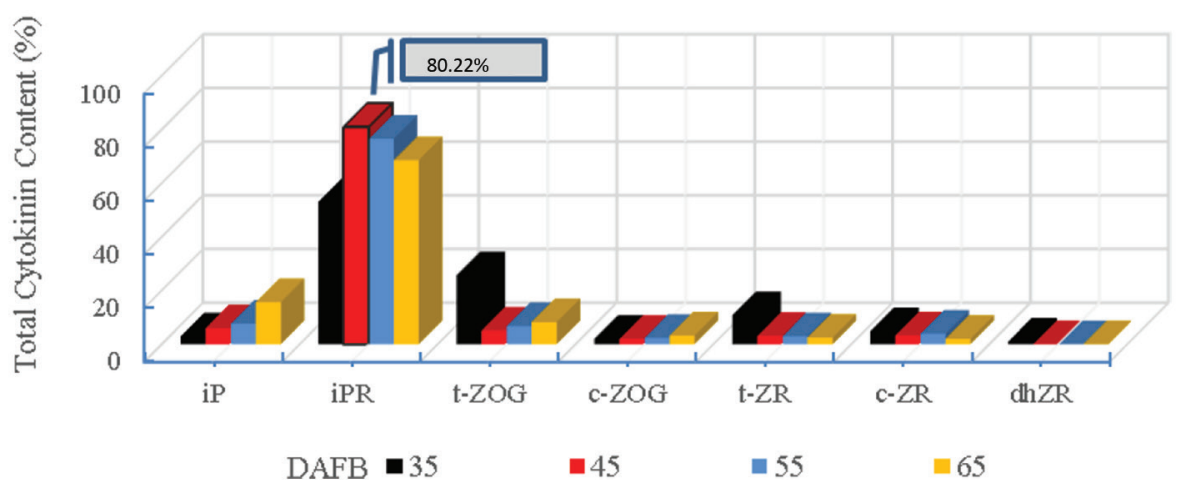

Figure 6. The main CK-like compounds detected in the panicles of only 'On'-year pistachio trees as a percentage of the total CK content. For explanation, see Figure 3.

\section{Concentration of CK-like compounds in nut samples}

The concentrations (ng $\cdot \mathrm{g}^{-1} \mathrm{DW}$ ) of the CK-like compounds in the pistachio nuts of only 'On'-year trees of the 'Uzun' pistachio cultivar are shown in Table 7. The CK concentrations in the nuts at different growth stages were significant at $p<0.05$. The main CKs, expressed as a percentage of the total CK content, are shown in Figure 7. In total, seven CKs were detected in the nuts (Table 6). Among the CKs, $t-Z O G$ (52.41-161.87 $\mathrm{ng} \cdot \mathrm{g}^{-1}$ DW in 'On' year) contributing over $65 \%$ of the total CK content were the dominant conjugates and showed the highest values; $c$-ZR $\left(1.38-1.85 \mathrm{ng} \cdot \mathrm{g}^{-1} \mathrm{DW}\right.$ in 'On' year) was found to have the lowest values (Table 7 and Figure 7). In this study, it was determined that the maximum levels of $t$-ZR and $t$-ZOG were 35 days after full flowering (end of May) and sharply decreased in June, 45 DAFB (Table 7). The concentrations of CKs (such as $t$-ZR and $t$-ZOG) were found to be higher than in the other organs (leaves and shoots). iP was found to be below the detection limit and $t-Z$ and $c-Z$ could not be detected in nut samples (Table 7).

\section{DISCUSSION}

In most cases, alternate bearing in fruit trees is the result of poor flower initiation, but in pistachio (P. vera L.), unlike in other fruit species, there are plenty of flower buds every year. Abscission of buds occurs during this quiescent period as well as at the stage when vigorous seed growth occurs in fruits in the current year (Monselise and Goldschmidt, 1982). Some investigators have suggested that excessive flower bud abscission in pistachio begins 
Table 7. Concentrations of CK-like compounds in the nuts in different physiological periods in only 'On'-year pistachio trees

\begin{tabular}{|c|c|c|c|c|c|c|}
\hline \multicolumn{7}{|c|}{$\begin{array}{c}\text { Nuts } \\
\text { CK content }\left(\mathrm{ng} \cdot \mathrm{g}^{-1} \mathrm{DW}\right) \\
\text { 'On' year }\end{array}$} \\
\hline & 35 DAFB & 45 DAFB & 55 DAFB & 65 DAFB & $\begin{array}{c}\text { Period } \\
\text { average }\end{array}$ & $\begin{array}{c}\text { D\%5 periods } \times \\
\text { 'On' year }\end{array}$ \\
\hline$t$-ZOG & $161.87^{\mathrm{a}} \pm 8.09$ & $56.55^{c} \pm 3.13$ & $52.41^{c} \pm 2.38$ & $74.51^{b} \pm 3.75$ & 86.34 & $9.13^{* *}$ \\
\hline$c-\mathrm{ZOG}$ & $2.42^{\mathrm{b}} \pm 0.14$ & $2.38^{\mathrm{b}} \pm 0.12$ & $1.56^{\mathrm{c}} \pm 0.07$ & $3.22^{\mathrm{a}} \pm 0.19$ & 2.65 & $0.25^{* *}$ \\
\hline$t-Z$ & $<$ LOD & $<\mathrm{LOD}$ & nd & nd & & \\
\hline$c-Z$ & nd & nd & nd & nd & & \\
\hline$t$-ZR & $184.85^{\mathrm{a}} \pm 9.24$ & $32.90^{\mathrm{b}} \pm 1.82$ & $24.18^{\mathrm{bc}} \pm 1.09$ & $21.51^{\mathrm{c}} \pm 1.20$ & 65.86 & $8.97^{* *}$ \\
\hline$c-\mathrm{ZR}$ & $1.81^{\mathrm{a}} \pm 0.10$ & $1.85^{\mathrm{a}} \pm 0.11$ & $1.45^{b} \pm 0.07$ & $1.38^{b} \pm 0.06$ & 1.62 & $0.14^{* *}$ \\
\hline Total Z type & 350.95 & 93.68 & 79.6 & 100.62 & & \\
\hline DHZ & $3.04^{\mathrm{a}} \pm 0.14$ & $2.80^{\mathrm{b}} \pm 0.15$ & $1.90^{\mathrm{c}} \pm 0.10$ & $1.17^{\mathrm{d}} \pm 0.06$ & 2.22 & $0.20^{* *}$ \\
\hline DHZR & $24.95^{\mathrm{a}} \pm 1.25$ & $7.23^{b} \pm 0.40$ & $7.18^{b} \pm 0.32$ & $5.83^{c} \pm 0.30$ & 11.29 & $1.28^{* *}$ \\
\hline Total DHZ type & 27.99 & 10.03 & 9.08 & 7 & & \\
\hline iP & $<\mathrm{LOD}$ & $<$ LOD & $<\mathrm{LOD}$ & $<\mathrm{LOD}$ & & \\
\hline iPR & $3.04^{\mathrm{a}} \pm 0.15$ & $1.67^{\mathrm{bc}} \pm 0.07$ & $1.86^{\mathrm{b}} \pm 0.11$ & $1.63^{\mathrm{c}} \pm 0.19$ & 2.05 & $0.19^{* *}$ \\
\hline Total iP type & 3.04 & 1.67 & 1.86 & 1.63 & & \\
\hline Total isoprenoid CKs & 381.98 & 105.38 & 90.54 & 109.25 & & \\
\hline
\end{tabular}

No $c-Z$ was detected in any of the samples. The results represent mean \pm standard error. $<$ LOD, below the limit of detection; nd, not detected. Different letters show statistically different levels. ${ }^{*} p<0.05 ; * * p>0.01$.

For explanation, see Table 3.

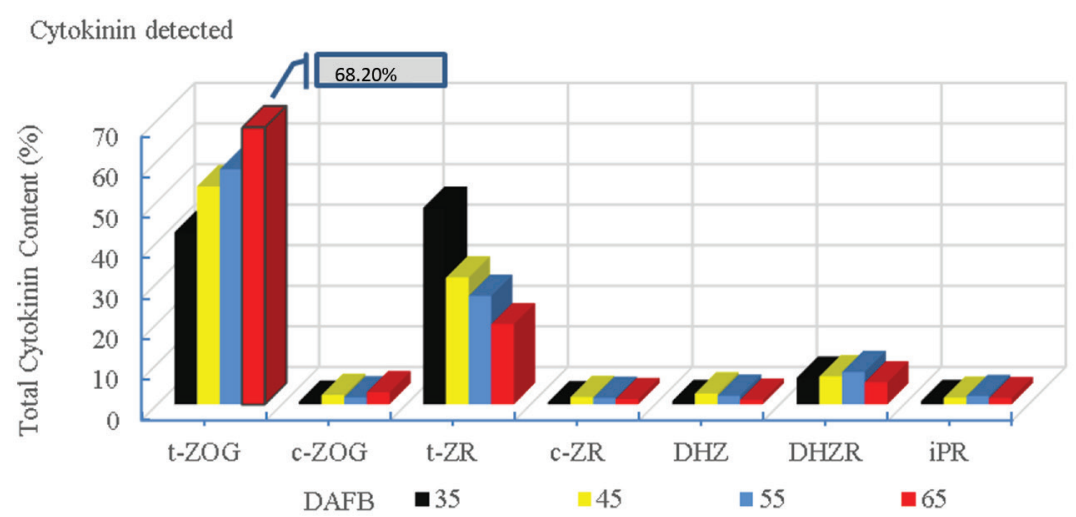

Figure 7. The main CK-like compounds detected in the nuts of only 'On'-year pistachio trees as a percentage of the total CK content. For explanation, see Figure 3.

in June in an 'On' year when embryo development increases during July and causes it to be an 'Off' year in the following year (Cetinkaya, 2004; Okay et al., 2011). However, microscopic examinations performed by us had shown that the rupturing layer in pistachio flower buds began to form in the last week. Evidence in various fruit species has been shown that PGRs have significant effects during the growth and development periods that they particularly control abscission (Lavee, 1989; Aziz et al., 2001; Baktir et al., 2004; Cetinkaya, 2004; Acar et al., 2006; Gomez-Jimenez et al., 2010; Okay et al., 2011; Gundesli et al., 2019). However, the importance of PGRs and the regulation of metabolic transformations are still largely unknown in fruit trees showing alternate bearing. Previous studies had reported that some physiological events, such as flower bud and embryo formation, development, flower bud abscission, fruit set and growth, are regulated by PGRs such as auxins, CKs, many gibberellins, abscisic acid, polyamines and ethylene. According to many studies, different PGRs have been externally applied in pistachio to obtain regular yield, increase flower bud formation and prevent flower bud abscission [Cetinkaya, 2004, Takeda and Crane, 1980 (Abscisic acid); Lin et al., 1984 (Gibberellic acid); Ferguson and Maranto, 1989 (auxin); Lovatt and Ferguson, 1998, 2001; Acar et al., 2006 (GA and CK); Lovatt et al., 2006, Okay et al., 2011 (auxin and CK); Aziz et al., 2001, Gomez-Jimenez et al., 2010, Gundesli et al., 2019 (polyamines)]. However, effective results could not be obtained in most of them because of insufficient data on the change in endogenous PGRs in the species involved. That is why recently, many studies 
have been carried out to explain the effects of CK-like compounds on plant growth and development. CK also mediates the responses to variable extrinsic factors, such as light conditions in the shoot and the availability of nutrients and water in the root, and it has a role in the response to biotic and abiotic stresses (Baktir et al., 2004; Cetinkaya, 2004; Davies, 2004; George et al., 2008; AlShdiefat and Qrunfleh, 2008; Okay et al., 2011; Sharma et al., 2019). The present study has given a fair insight into the status of CK-like compounds during bud abscission in $P$. vera $L$.. Using the latest available technology, the CKs in the different organs were identified and quantified. Concentrations of CK-like compounds in different growth periods and organs were determined in the 'Uzun' cultivar (Tables 3-7). There were statistically significant differences between the organs and almost all $\mathrm{CK}$ ratios in the 'On'-year and 'Off'-year trees for most of the periods of the experiment $(p<0.05)$. The results of the present investigation clearly show the presence of only four types of CK in different tissues, namely zeatin, zeatin riboside, zeatin glucoside and zeatin riboside glucoside (Tables 3-7 and Figures 3-7). This is evident from the results obtained by high-performance liquid chromatography with mass spectrometric detection (HPLC-ESI-MS/MS). In many studies, the physiological responses in flower bud and embryo formation, development, flower bud abscission, fruit set and growth performed by plants are thought to be due to CKs. Recently, many metabolites have been identified for CK-like compounds, but their importance and regulation of metabolic changes are still largely unknown (Ahmadi and Baker, 2000; Baktir et al., 2004; Stirk et al., 2004; Toker et al., 2006; Bajguz and Piotrowska, 2009; Okay et al., 2011). The most biologically active CKs are $t-\mathrm{Z}, \mathrm{DHZ}$ and 2iP, while $c-\mathrm{Z}$ is thought to exhibit poor activity or none. However, it has been reported that $c i s$-isomers are the main forms of CK in different plants (Emery et al., 2000; Sakakibara, 2006; Bajguz and Piotrowska, 2009). In this study, endogenous CK-like compounds were determined in the different organs and growth periods. We detected and quantified three groups of CK components: Z, Ip and DHZ in different tissues during flower bud abscission and kernel development. This is the first report on different types of CKs found before and after flower bud abscission. In particular, iPR and $t$-ZOG were found to be predominant forms of CK, which may be precursors of the biologically active $\mathrm{CK} \mathrm{s}$, and they were present at high concentrations (Table 3-7). These results agree with those of Ahmadi and Baker (2000), Ulvskov et al. (1992), Stirk et al. (2004), Lulsdorf et al. (2013), who found similar CKs, including the CK-like types in different plants. It is known that changes in CK activity are associated with plant growth and vary among plant organs (Palmer and Palni, 1987; Grayling and Hanke, 1992; Nooden and Letham, 1993; Sakakibara, 2006). Some researchers have identified many CKs in different plant species (Sab et al., 1985; Martin et al., 1987; Wagner and Beck, 1993; Komor et al., 1993; Ito et al., 2001; Novak et al., 2003; Stirk et al., 2004; Karady et al., 2011). In fact, more than $80 \%$ of the
Z-type CK content in Urtica dioica and Rosa hybrida, as reported by Dieleman et al. (1997) and Wagner and Beck (1993), was consistent with our results.

In the present study, a high $\mathrm{CK}$ concentration was detected at a very early stage, which increased progressively and reached a peak as the flower bud abscission started and then decreased to a low level in the flower bud abscission period (55 DAFB - June) (Table 3-7). Other reports of seasonal variations in CK content in different plants have shown high levels of CKs in the flowering and development stages and then low levels in later periods. The patterns of changes in $\mathrm{CK}$ activity in different plants are in agreement with the findings of some researches (Doumas and Zaerr, 1988; Komor et al. 1993; Novak et al., 2003; Cetinkaya, 2004; Okay et al., 2011; Lulsdorf et al., 2013). Leaf and shoot CK contents were higher in 'On' than in 'Off' trees, while flower buds had a higher amount in 'Off' than 'On' trees. Cetinkaya (2004), Okay et al. (2011) (pistachio) and Baktir et al. (2004) (olive) found similar results. $t$-ZOG, $t$-ZR, $c$-ZR and iPR were found to be higher in the shoots than in the leaves. Although DHZR was found in nut samples, it was not detected in the other organs. $t-Z$ was detected in shoot samples but not in leaf samples (Tables 3 and 4). CK contents were found to be higher in the panicles compared with the other organs (shoot, leaf and flower bud). The $t$-Z content of panicles was higher before fruit-bud abscission, but iP was low; however, the $t-Z$ content decreased during fruit-bud abscission and kernel development periods, while the iP content increased (Tables 6 and 7 and Figures 3-7). The pattern of changes in $\mathrm{CK}$ activity was in agreement with the findings of Niimi and Torikata (1978). This suggests that there are different changes between the panicle and fruit in terms of CK activity. As a result, it is thought that different CKs are active in different organs of pistachio trees. Results presented elsewhere (Davies, 1995; Ito et al., 2001; Baktir et al., 2004) indicate that at least some of the CK supply entering into the flower passes into the leaves, and some may also pass into other developing organs, similar to our findings. As can be understood from this research, in addition to the amounts of CK that are synthesised in different parts of pistachio trees, flower bud abscission and fruit development periods reveal the activity of CKs. As a result, CK contents were high in the period just prior to flower abscission and low in subsequent stages. Indeed, Lovatt and Ferguson (1998, 2001) and Lovatt et al. (2006) had reported that the levels of CK in pistachio flower buds were low as a result of the effects of ageing, and especially during flower bud abscission, which was similar to our results. In many studies, PGRs have been applied exogenously to achieve regular yields of pistachio nuts to increase the formation of flower buds and to prevent flower bud and fruit abscission (Lovatt and Ferguson, 1998; Acar et al., 2006; Talaie et al., 2006; Lovatt et al., 2006; Vemmos, 2010). However, this is still not very effective. For this reason, it is very important to know the CKs in pistachio in different growth periods to explain the 
physiological mechanisms such as flower bud formation, and flower and flower bud abscission (alternate bearing). The data obtained in this study show a general relationship between CK-like compounds and flower bud abscission in pistachio trees. Due to this research, it can be concluded that the effect of fruit growth can be influenced by successful exogenous growth regulator applications in periods of slow and low synthesis of CK-like compounds, especially in the determination of effective application periods. Interestingly, the relatively high CK activity was recorded just before flower bud abscission in the fractions corresponding to iP and ZR.

\section{CONCLUSIONS}

In the present investigation, an experiment was conducted to record the changes in CK-like compounds during flower bud abscission in $P$. vera 'Uzun'. In contrast to the studies previously reported in pistachio, CK-like compounds were identified in different organs and growth periods. To the best of our knowledge, this is the first report on CK-like compounds in pistachio. CK activity has been shown to have important effects during flower bud abscission and kernel development. Four CK types, namely zeatin, zeatin riboside, zeatin glucoside and zeatin riboside glucoside were detected. iPR and $t$-ZOG were the main and dominant CK-like compounds in all the organs analysed, and $t-Z, t-Z R$, $c$-ZR and DHZR followed, respectively. According to the results, especially iPR and $t$-ZOG declined during the heavy bud abscission period in 'On'-year trees. In most cases, the concentrations of CK-like compounds in organs from 'On'-year trees were lower than from those of 'Off'-year trees. The strong negative correlation between CK-like compounds and bud abscission could be the first indication of the role of CK-like compounds in this unique phenomenon in the 'Uzun' pistachio cultivar. Thus, exogenous application of CK-like compounds in different concentrations is suggested for further studies to mitigate alternate bearing in pistachio. In conclusion, the relative amount of a specific form of CK may differ not only from one form to another but also in one particular plant tissue under different physiological conditions. This study clearly demonstrated that CKlike compounds play an important role in bud abscission and cause alternate bearing in pistachio.

\section{ACKNOWLEDGEMENTS}

This work was supported by grants from the Cukurova University Scientific Research Project (No. ZF2013D23) and many thanks to Nevzat Aslan, Mozhgan Zarifikhosroshahi, Sina Kefayati, Harun Karci and Hayat Topcu for technical assistance in this experiment. Also thanks for material support to the Republic of Turkey Ministry of Food, Agriculture and Livestock - General Directorate of Agricultural Research and Policies. We also express special thanks to the National Research Council of Canada for hormone profiling sample preparation and data analysis (UPLC-ESI-MS/MS).

\section{AUTHOR CONTRIBUTIONS}

M.A.G., S.K., M.G. and N.E.K. contributed equally to this manuscript. All of the authors contributed to the discussion of the results, and all of them read and approved the final manuscript.

\section{CONFLICT OF INTEREST}

The authors declare that they have no conflict of interest.

\section{REFERENCES}

Acar, I., Tahtaci, S. A., Arpaci, S., Aydin, Y., and KaradaG, S., (2006). Determination of effects of plant growth regulator applications on alternate bearing in pistachios under suitable growing conditions. Acta Horticulturae, 726(1), 539-544.

Achard, P., Cheng, H., De Graume, L., Decat, J., Schoutteten, H., Moritz, T., Van Der Straeten, D., Peng, J., ANd Harberd, N. P. (2006). Integration of plant responses to environmentally activated phytohormonal signals. Science, 311(5757), 91-94.

Ahmadi, M., AND BAKer, D. A., (2000). Identification and quantification of the major endogenous cytokinins in pistachio seedlings. Plant Growth Regulation, 32, 351-357.

Al-shdiefat, S., And QRunfleh, M., (2008). Alternate bearing of the olive (Olea europaea L.) as related to endogenous hormonal content. Jordan Journal of Agricultural Sciences. 4, 12-25.

Atri, H. S., Arpaci, S., Akgun, A., And Acar, I., (2003). Cultivar-rootstock combinations for unirrigated pistachio in Turkey. Acta Horticulturae, 622, 567-571.

Aziz, A., Brun, O., AND Audran, J. C., (2001). Involvement of polyamines in the control of fruitlet physiological abscission in grapevine (Vitis vinifera). Physiologia Plantarum, 113(1), 50-58.

Bajguz, A., And Piotrowska, A. (2009). Conjugates of auxin and cytokinin. Phytochemistry, 70(8), 957-969.

BAKtiR, I., Ulger, S., AND KAYNAK, L. (2004). Relationship of seasonal changes in endogenous plant hormones and alternate bearing of olive trees. HortScience, 39(5), 987-990.

BAngerth, F. (2006). Flower induction in perennial fruit trees: Still an enigma? Acta Horticulturae, 727, 177-195.

Baninasab, B., and Rahemi, M. (2006). Possible role of non-structural carbohydrates in alternate bearing of pistachio. European Journal of Horticultural Science, 71, 277-282.

Bons, H. K., Kaur, N., and Rattanpal, H. S. (2015). Quality and quantity improvement of citrus: Role of plant growth regulators. International Journal of Agriculture Environment \& Biotechnology, 8(2), 433-447.

Brown, P. H., Weinbaum, S. A., and Piccioni, G. A. (1995). Alternate bearing influences annual nutrient consumption and total nutrient content of mature pistachio trees. Trees, 9, 158-168. 
Cetinkaya, H. (2004). Relationship between alternate bearing and levels of hormones, carbohydrate and plant nutrients on some pistachio cultivars bearing complete or rational alternately. PhD Dissertation, Institute of Natural and Applied Sciences, University of Cukurova, Turkey, pp. 194.

Chiwocha, S. D. S., Abrams, S. R., Ambrose, S. J., Cutler, A. J., Loewen, M., Ross, A. R. S., And Kermode, A. R. (2003). A method for profiling classes of plant hormones and their metabolites using liquid chromatography-electrospray ionization tandem mass spectrometry: Analysis of hormone regulation of thermodormancy of lettuce (Lactuca sativa L.) seeds. Plant Journal, 35(3), 405-417.

Chiwocha, S. D. S., Cutler, A. J., Abrams, S. R., Ambrose, S. J., Yang, J., Ross, A. R. S., And Kermode, A. R. (2005). The etr1-2 mutation in Arabidopsis thaliana affects the abscisic acid, auxin, cytokinin and gibberellin metabolic pathways during maintenance of seed dormancy, moist-chilling and germination. Plant Journal, 42(1), 35-48.

Dag, A., Bustan, A., Avni, A., Tzipori, I., Lavee, S., And Riov, J. (2010). Timing of fruit removal affects concurrent vegetative growth and subsequent return bloom and yield in olive (Olea europaea L.). Scientia Horticulturae, 123, 469-472.

Davies, P. J. (1995). Plant hormones: Physiology, biochemistry and molecular biology. Dordrecht, The Netherlands; Norwell, MA, USA: Kluwer Academic Publishers.

DAvies, P. J. (2004). Plant hormones: Their nature, occurrence and function. In P.J. Davies (Ed.), Plant hormones: Biosynthesis, signal transduction, action (3rd edn., pp. 1-15). Dordrecht, Netherlands: Kluwer Academic Publishers.

Dieleman, J. A., Verstappe, F. W. A., Perik, R. R. J., AND KuIPER, D. (1997). Quantification of the export of cytokinins from roots to shoots of Rosa hybrida and their degradation rate in the shoot. Physiologia Plantarum, 101, 347-352.

Doumas, P., AND ZAerr, J. B. (1988). Seasonal changes in levels of cytokinin-like compounds from Douglasfir xylem extrudate. Tree Physiology, 4, 1-8.

Emery, R. J. N., Ma, Q., And Atkins, C. A. (2000). The forms and sources of cytokinins in developing lupine seeds and fruits. Plant Physiology, 123, 1593-1604.

Ferguson, L., And Maranto, J. (1989). Effects of growth regulators on pistachio inflorescence and bud retention. California Pistachio Industry Annual Report Crop Year 1988-1989, pp. 91-92.

Foster, T., Johnston, R., And Seleznyova, A. (2003). A morphological and quantitative characterization of early floral development in apple (Malus $\times$ domestica Borkh.). Annals of Botany, 92, 199-206.

George, E. F., Hall, M. A., and Klerk, D. E. (Eds) (2008). Plant propagation by tissue culture, Dordrecht, Netherlands: Springer.

Goldschmidt, E. E. (2013). The evolution of fruit tree productivity: A review. Economic Botany, 67, 51-62.
Gomez-Jimenez, M. C., Parades, M., Gallardo, M. S., AND IsABEL, M. (2010). Mature fruit abscission is associated with up-regulation of polyamine metabolism in the olive abscission zone. Journal of Plant Physiology, 167(17), 1432-1441.

Grayling, A., And Hanke, D. E. (1992). Cytokinins in exudates from leaves and roots of red Perilla. Phytochemistry, 31, 1863-1868.

Gundesli, M. A. (2017). Determination of mechanism of bud abscission in pistachio. PhD Dissertation, Institute of Natural and Applied Sciences, University of Cukurova, Turkey, pp. 353.

Gundesli, M. A., Kafkas, S., Zarifikhosroshahi, M., AND KafKAS, N. E. (2019). Role of endogenous polyamines in the alternate bearing phenomenon in pistachio. Turkish Journal of Agriculture and Forestry, 43, 265-274.

Ito, A., Hayama, H., Kashimura, Y., and Yoshioka, H. (2001). Effect of maleic hydrazide on endogenous cytokinin contents in lateral buds, and its possible role in flower bud formation on the Japanese pear shoot. Scientia Horticulturae, 87, 199-205.

Kamada-Nobusada, T., AND SAKakiba, H. (2009). Molecular basis for cytokinin biosynthesis. Phytochemistry, 70(4), 444-449.

Karady, M., Novk, O., Horna, A., Strnad, M., And Dolezal, K. (2011). Performance Liquid Chromatography-Electrochemistry Electrospray Ionization Mass Spectrometry (HPLC/EC/ESI-MS) for detection and characterization of roscovitine oxidation products. Electroanalysis, 23(12), 2898-2905.

Komor, E., Liegl, I., And Schobert, C. (1993). Loading and translocation of various cytokinins in phloem and xylem of the seedlings of Ricinus communis L. Planta, 191, 252-255.

Koshita, Y., And TAKahara, T. (2004). Effect of water stress on flower-bud formation and plant hormone content of satsuma mandarin (Citrus unshiu Marc.). Scientia Horticulturae, 99, 301-307.

Kuden, A. B., Kaska, N., TAnriver, E., Tekin, H., And Ak, B. E. (1995). Determining the chilling requirements and growing degree hours of some pistachio nut nultivars and regions. Acta Horticulturae, 419, 85-90.

LAVEE, S. (1988). Involvement of plant growth regulators and endogenous growth substances in the control of alternate bearing. In VI International Symposium on Growth Regulators in Fruit Production 239 (pp. 311-322).

LAvee, S. (2007). Biennial bearing in olive (Olea europaea). Annales, Series Historia Naturalis, 17, 101-112.

Lin, T. S., Crane, J. C., and Ryugo, K. (1984). Effects of gibberellic acid on vegetative and inflorescence buds of pistachio. Journal of the American Society for Horticultural Science, 109(1), 39-42.

Lovatt, C. J., And Ferguson, L. (1998). Using foliar application of urea combined with 6-benzyladenin to decrease pistachio floral bud abscission in an 
'on' year to increase yield the next year. California Pistachio Industry Annual Report, pp. 155-158.

Lovatt, C. J., And Ferguson, L. (2001). Urea combined with 6-benzyladenin to reduce alternate bearing in pistachio and to increase cumulative yield (Fifth Year Report). California Pistachio Industry Annual Report, pp. 151-152.

Lovatt, C. J., Daoudi, H., And Ferguson, L. (2006). Efficacy of foliar-applied cytokinins and nitrogen to increase floral bud retention and to reduce alternate bearing of pistachio. Acta Horticulturae, 727, 353-364.

Lulsdorf, M. M., Yuan, H. Y., Slater, S. M., VandenberG, A., Han, X., ANd Zaharia, L. I. (2012) Androgenesisinducing stress treatments change phytohormone levels in anthers of three legume species (Fabaceae). Plant Cell Reports, 31, 1255-1267.

Lulsdorf, M. M., Yuan, H. Y., Slater, S. M., Vandenberg, A., Han, X., Zaharia, L. I., AND Abrams, S. R. (2013). Endogenous hormone profiles during early seed development of $C$. arietinum and $C$. anatolicum. Plant Growth Regulation, 71, 191-198.

Martin, L., Diez, A., Nicolas, G., Legaz, M. E., And Villalobos, N. (1987). Cytokinins in chick-pea seeds identification and transformation during germination and seedling growth. Journal of Plant Physiology, 128, 133-140.

Mok, D. W., And Mok, M. C. (2001). Cytokinin metabolism and action. Annual Review of Plant Physiology and Plant Molecular Biology, 52, 89-118.

Monselise, S. P., And Goldschmidt, E. E. (1982). Alternate bearings in fruit trees. Horticultural Reviews, 4, 128-73.

NiImi, Y., AND ToRikata, H. (1978). Changes in cytokinin activities, photosynthesis and respiration of the grape flower clusters during their development. Journal of the Japanese Society for Horticultural Science, 47, 301-307.

Nooden, L. D., and Letham, D. S. (1993). Cytokinin metabolism and signalling in the soybean plant. Australian Journal of Plant Physiology, 20, 639-653.

Novak, O., TARKowski, P., TARKowsKa, D., Dolezal, K., Lenobel, R., and Strnad, M. (2003). Quantitative analysis of cytokinins in plants by liquid chromatography/single-quadrupole mass spectrometry. Analytica Chimica Acta, 480, 207-218.

Okay, Y., Gunes, N. T., And Koksal, A. (2011). Free endogenous growth regulators in pistachio (Pistacia vera L.). African Journal of Agricultural Research, 6(5), 1161-1169.

Palmer, M. V., and Palni, L. M. S. (1987). Substrate effects on cytokinin metabolism in soybean callus tissue. Journal of Plant Physiology, 126, 365-371.

Palmer, M. V., And Wong, O. C. (1985). Identification of cytokinins from xylem exudate of Phaseolus vulguris L. Plant Physiology, 79, 296-298.

Picchioni, G. A., Brown, P. H., Weinbaum, S. A., And MuraokA, T. T. (1997). Macronutrient allocation to leaves and fruit of mature, alternate bearing pistachio trees: Magnitude and seasonal patterns at the whole-canopy level. Journal of the American Society for Horticultural Science, 122 (2), 267-274.

Rosenstock, T. S., Rosa, U. A., Plant, R. E., And Brown, P. H. (2010). A reevaluation of alternate bearing in pistachio. Scientia Horticulturae, 124, 149-152.

Sab, T., Macleod, J. K., Palni, L. M. S., and Letham, D. S. (1985). Detection of cytokinins in a seaweed extract. Phytochemistry, 24, 2611-2614.

SAKakibara, H. (2006) Cytokinins: Activity, biosynthesis, and translocation. Annual Review of Plant Biology, 57, 431-449.

Sharma, N., Singh, S. K., Mahato, A. K., Ravishankar, H., Dubey, A. K., And Singh, N. K. (2019). Physiological and molecular basis of alternate bearing in perennial fruit crops. Scientia Horticulturae, 243, 214-225.

Sharma, N., Singh, S. K., Singh, N. K., Srivastav, M., Singh, B. P., Mahat, A. K., And Singh, J. P. (2015). Differential gene expression studies: A possible way to understand bearing habit in fruit crops. Transcriptomics Open Access, 3(110), 10-12.

Stirk, W. A., Arthur, G. D., Lourens, A. F., Novak, O., Strnad, M., and Van Staden, J. (2004). Changes in cytokinin and auxin concentrations in seaweed concentrates when stored at an elevated temperature. Journal of Applied Phycology, 16, 31-39.

Takeda, F., And Crane, J. C. (1980). Abscisic acid in pistachio as related to inflorescence bud abscission. Journal of the American Society for Horticultural Science, 105, 573-576.

Talaie, A. R., Eyedi, M., Panah, B., and Khezri, M. (2006). Effects of shoot girdling and urea combined with 6-benzyl adenine on abscission of inflorescence buds in "Ohadi" pistachio cultivar (Pistacia vera L.). International Journal of Agriculture and Biology, 8(4), 474-476.

Toker, C., Ulger, S., And Cagirgan, M. I. (2006). Endogenous hormone variations in annual wild Cicer species. Genetic Resources and Crop Evolution, 53(1):171-177.

Ulviskov, P., Nielsen, T. H., Seiden, P., And Marcussen, J. (1992). Cytokinins and leaf development in sweet pepper (Capsicum annuum L.) I. Spatial distribution of endogenous cytokinins in relation to leaf growth. Planta, 188, 70-77.

Vemmos, S. N. (1999a). Carbohydrate content of inflorescent buds of defruited and fruiting pistachio (Pistacia vera L.) branches in relation to biennial bearing. The Journal of Horticultural Science and Biotechnology, 74(1), 94-100.

Vemmos, S. N. (1999b). Mineral composition of leaves and inflorescent buds in fruiting and non-fruiting pistachio trees. Journal of Plant Nutrition, 22, 1291-1301.

Vemmos, S. N. (2010). Alternate bearing and the possible role of carbohydrates in bud abscission of pistachio (Pistacia vera L.). In G. Zakynthinos (Ed.), XIV GREMPA Meeting on Pistachios and Almonds. Zaragoza: CIHEAM/FAO/AUA/TEI Kalamatas/ NAGREF, 2010.pp. 9-18(Options Méditerranéennes: Série A. Séminaires Méditerranéens; n. 94). 
Wagner, B. M., AND Beck, E. (1993). Cytokinins in the perennial herb Urtica dioica $\mathrm{L}$. as influenced by its nitrogen status. Planta, 190, 511-518.

Weinbaum, S. A., Picchioni, G. A., Muraoka, T. T., Brown, P. H., And Ferguson, L. (1994). Nitrogen usage, accumulation of carbon and nitrogen reserves, and the capacity for labelled fertilizer nitrogen and boron uptake varies during the alternate-bearing cycle in pistachio. Journal of the American Society for Horticultural Science, 119, 24-31.

Yavuz, G. G. (2011). Sert Kabuklu Meyveler/Antep Fıstığı. TEPGE BAKIŞ, Tarımsal Ekonomi Ve Politika Geliştirme Enstitüsü, Aralık 2011/ISSN: 1303-8346/Nüsha: 5, Ankara. Turkey.

Received September 24, 2019; accepted November 20, 2019 